\title{
PERAN KOMISI INFORMASI PUBLIK DALAM PROSES EKSEKUSI TERHADAP PUTUSAN SENGKETA INFORMASI YANG BERKEKUATAN HUKUM TETAP DALAM TINJAUAN UU NO.14 TAHUN 2008 TENTANG KETERBUKAAN INFORMASI PUBLIK
}

\author{
Slamet Haryanto Dan Kadi Sukarna
}

\begin{abstract}
ABSTRAK
Masyarakat sebagai pengguna informasi memiliki hak yang cukup penting dalam konteks keterbukaan informasi, ketika hak untuk memperoleh informasi terhambat dikarenakan badan publik atau pemerintah tidak siap dalam melaksanakan tata kelola keterbukaan informasi, maka sengketa informasi publik akan muncul dalam pelaksanaan keterbukaan informasi publik

Sengketa informasi publik terjadi ketika antara badan publik dan pengguna informasi mengalami sengketa yang berkaitan dengan hak-hak memperoleh informasi dan menggunakan informasi berdasarkan perundang-undangan. Penyelesaian sengketa melalui ajudikasi nonlitigasi merupakan proses dari penyelesaian sengketa informasi publik. Dimana penyelesaian sengketa informasi melalui ajudikasi nonlitigasi tersebut diharapkan mampu untuk menyelesaikan sengketa dengan cepat, biaya murah, sederhana.

Adapun permasalahan dalam tesis ini adalah : a).bagaimana mekanisme penyelesaian sengketa informasi publik di Komisi Informasi, b).bagaimana kendala dan solusi pelaksanaan eksekusi putusan Komisi Informasi yang telah berkekuatan hukum tetap

Menjawab permasalah tersebut dilakukanlah penelitian dengan metode pendekatan yuridis normatif dengan spesifikasi penelitian deskriptif analitis. Jenis data yang digunakan dalam penelitian ini adalah data sekunder.

Penelitian yang telah dilakukan diperoleh temuan bahwa Prosedur Penyelesaian Sengketa Informasi Publik, eksekusi putusan atau pelaksanaan putusan Komisi Informasi yang telah berkekuatan hukum tetap dilakukan oleh Pengadilan yang berwenang, dalam konteks penyelesaian sengketa informasi publik disini adalah pengadilan dalam wilayah hukum termohon. Dalam hal ini jika termohon adalah badan publik Negara atau Pemerintah maka pengadilan yang dimaksud adalah Pengadilan Tata Usaha Negara, sedangkan jika termohon eksekusi adalah pihak diluar badan publik Negara atau Pemerintah maka pengadilan yang berwenang adalah Pengadilan Negeri yang berwenang

Kewenangan eksekusi putusan Komisi Informasi yang diberikan kepada Pengadilan Tata Usaha Negara maupun Pengadilan Negeri, menyebabkan pengguna informasi mengalami proses yang cukup panjang untuk memperoleh informasi yang menjadi kebutuhan atau hak konstitusionalnya
\end{abstract}

Kata kunci : sengketa informasi publik, putusan komisi informasi, eksekusi 


\title{
THE ROLE OF PUBLIC INFORMATION COMMISSION IN THE EXECUTION PROCESS ON THE DECISION OF THE INFORMATION LAWSUIT WHICH IS LEGALLY BINDING IN THE REVIEW OF ACT NO.14 YEAR 2008 ON THE DISCLOSURE OF PUBLIC INFORMATION
}

\author{
Slamet Haryanto and Kadi Sukarna
}

\begin{abstract}
The community as the users of information has sufficiently important rights in the context of information disclosure. When the right to obtain information is inhibited because the public entity or governor is not available in the execution of the information disclosure management, then public information lawsuit will emerge in the implementation of the public information disclosure.

The public information lawsuit happens when public entity and the user of information disputes with something related to the rights to acquire information and to use information based on legislation. The completion of the lawsuit through nonlitigation ajudication is the process of the completion of public information lawsuit. The completion of the information through nonlitigation ajudication is hopefully able to resolve the dispute fast, low cost, and simple.

The problems in this thesis are: a) how the mechanisms of the settlement of public information lawsuit in the Information Commission, b) what obstacles and solutions of the execution implementation of the Information Commission decisions which have been legally binding.

Answering the problem, research with juridical normative approach method with analytical descriptive research specification was conducted. The type of data used in this study is secondary data.

Based on the research that had been conducted, it was found that Public Information Lawsuit Settlement Procedure, the execution of the decision or the execution of the Information Commission decision which had been legally binding was conducted by the competent Court, in the context that the public information lawsuit settlement was the court within the jurisdiction of the pleated. In this case if the pleated is State or Government public entity then the court in question is the Administrative Court of the State, whereas if the execution pleated is a party outside the State or Government public entity then the competent court is the competent District Court.

The execution authority of the Information Commission decision granted to the State Administrative Court as well as the District Court, causes the information users to experience the long process of obtaining information which is their needs or constitutional rights.
\end{abstract}

Keywords: public information lawsuit, information commission decision, execution 


\section{PENDAHULUAN}

Kemampuan masyarakat
untuk mencari, memperoleh,
memiliki, menyimpan, mengolah dan
menyampaikan informasi mengenai
kinerja pemerintahan sangat penting
bagi transparansi dan akuntabilitas
yang menjadi ciri suatu masyarakat
terbuka sebab informasi publik
merupakan informasi yang
dihasilkan, disimpan, dikelola,
dikirim, dan/atau diterima oleh suatu
badan publik yang berkaitan dengan
penyelenggara dan penyelenggaraan
Negara dan/atau penyelenggara dan
penyelenggaraan badan publik
lainnya

Tata kelola pemerintahan
yang baik, mensyaratkan
pemerintahan yang terbuka dan

kebebasan memperoleh informasi untuk menjadi salah satu pondasinya. Pemerintahan yang terbuka mensyaratkan adanya lima jaminan, yaitu : pertama hak untuk memantau prilaku pejabat publik dalam menjalankan peranya; kedua hak untuk memperoleh informasi; ketiga hak untuk terlibat dan berpartisipasi dalam proses pembentukan kebijakan publik; keempat kebebasan berekspresi; kelima hak untuk mengajukan keberatan terhadap penolakan atas keempat hak tersebut Meskipun telah ada perubahan paradigma dalam penyelenggaraan pemerintahan melalui tata kelola keterbukaan informasi, dalam tataran empiris pelayanan publik juga masih mengalami ketertutupan dan bahkan sistem informasi tata kelola keterbukaan juga masih memberikan sedikit informasi yang berkaitan dengan kebijakan publik. Informasiinformasi yang sekiranya menurut pemerintah menjadi permasalahan dikemudian hari sering tidak diinformasikan kepada pengguna informasi sehingga obyek informasi tersebut menjadi sengketa informasi.

$$
\text { Munculnya sengketa }
$$

informasi publik terjadi ketika antara badan publik dan pengguna informasi mengalami sengketa yang berkaitan dengan hak-hak memperoleh informasi dan menggunakan informasi berdasarkan perundang-undangan yang berkaitan dengan keterbukaan informasi publik. 
Proses penyelesaian sengketa informasi publik dilaksanakan dengan menggunakan mekanisme mediasi dan/atau ajudikasi nonlitigasi, dimana sengketa tersebut diajukan oleh pemohon informasi kepada Komisi Informasi dalam tempo 14 (empat belas) hari semenjak diterimanya tanggapan tertulis dari atasan pejabat ${ }^{1}$ pengelola informasi dan dokumentasi badan publik. Dan dalam penyelesaian sengketa informasi publik yang dilakukan oleh Komisi Informasi memiliki batas waktu 100 (seratus) hari kerja ${ }^{2}$ dimulai sidang ajudikasi nonlitigasi hingga putusan Komisi Informasi

Kondisi yang demikian menjadi salah satu proses yang sangat panjang bagi pemohon atau pengguna informasi yang hanya sekedar untuk memperoleh informasi publik dengan cepat, sederhana dan biaya ringan

Bagaimanakah jika ada putusan Komisi Informasi yang telah berkekuatan hukum tetap untuk

\footnotetext{
${ }^{1}$ Pasal 37 ayat (2) UU No.14 tahun 2008 tentang Keterbukaan Informasi Publik ${ }^{2}$ Pasal 38 ayat (2) UU No.14 tahun 2008 tentang Keterbukaan Informasi Publik
}

dilakukan eksekusi ? apakah eksekusi terhadap putusan Komisi Informasi yang telah berkekuatan hukum tetap tersebut dapat dijalankan oleh Komisi Informasi ? sehingga jaminan keadilan dan perlindungan hukum bagi pemohon atau pengguna informasi untuk mendapatkan informasi dapat berjalan dengan cepat, sederhana dan biaya ringan.

\section{PEMBAHASAN}

Mendasarkan ketentuan pasal 60 ayat (4) Peraturan Komisi Informasi No.1 tahun 2013 tentang Prosedur Penyelesaian Sengketa Informasi Publik, eksekusi putusan atau pelaksanaan putusan Komisi Informasi dilakukan oleh Pengadilan yang berwenang. Pengadilan yang berwenang tersebut pengadilan dalam wilayah hukum termohon.

Melalui kewenangan eksekusi putusan Komisi Informasi diberikan oleh pengadilan diwilayah hukum termohon, dalam hal ini jika termohon adalah badan publik Negara atau Pemerintah maka pengadilan yang dimaksud adalah Pengadilan Tata Usaha Negara, 
sedangkan jika termohon eksekusi adalah pihak diluar badan publik Negara atau Pemerintah maka pengadilan yang berwenang adalah Pengadilan Negeri yang berwenang

Sebagaimana didalam ketentuan Undang-undang Keterbukaan Informasi Publik maupun Peraturan Komisi Informasi, Komisi Informasi tidak memiliki kewenangan untuk melakukan eksekusi putusannya sendiri. Kewenangan eksekusi putusan yang tidak dimiliki oleh Komisi Informasi secara kelambagaan menyebabkan pemohon selaku pihak yang berperkara akan mengalami proses untuk memperoleh informasi yang cukup tidak efektif, tidak efisien serta biaya tinggi.

Kondisi yang demikian menurut pandangan Jhon Austin, untuk mencapai (kepastian hukum) hukum harus dipisahkan dari moral. Hans Kelsen menjelaskan bahwa hukum tidak hanya dilepaskan dari persoalan moral melainkan juga harus dimurnikan dari anasir non hukum seperti filsafat, politik, psikologi, ekonomi, dan sosial. ${ }^{3}$ Kepastian hukum atau rechtssicherkeit, security, rechtzekerheit, adalah sesuatu yang baru, yaitu sejak hukum itu ditulis, dipositifkan, dan menjadi publik. Kepastian hukum menyangkut masalah "law Sicherkeit durch das Recht" seperti memastikan, bahwa pencurian, pembunuhan, menurut hukum merupakan kejahatan. Kepastian hukum adalah "scherkeit des rechts selbst" (kepastian tentang hukum itu sendiri). ${ }^{4}$

Menurut Gustav Radbruch, hukum harus mengandung tiga nilai identitas. (1) Teori Kepastian Hukum atau rechtmatigheid. Teori ini meninjau dari sudut yuridis. (2) Teori Keadilan Hukum (gerectigheit), asas ini meninjau dan sudut filosofis. (3) Teori Kemanfaatan Hukum (zwechmatigheid) atau doelmatigheid atau utility. Teori ini meninjau dari

\footnotetext{
3 Sulistyowati Irianto \& Shidarta, Metode Penelitian Hukum Konstelasi dan Reflekasi, Jakarta: Yayasan Pustaka Obor Indonesia, 2013, hlm. 15

4 Ahmad Ali, 2010, Menguak Teori Hukum (Legal Theory) dan Teori Peradilan (Judicialprudence) Termasuk Interpretasi Undang-Undang (Legisprudence), Jakarta: Kencana Prenada Media Group, 2010, hlm. 292.
} 
sosiologis. ${ }^{5}$ Pada mulanya, ajaran prioritas dari Gustav Radbruch dirasakan jauh lebih maju dan arif, ketimbang "ajaran ekstrem", yaitu ajaran etis, utilistis, dan dogmaticlegalistik. Namun lama-kalamaan, karena semakin kompleknya kehidupan manusia di era modern ini, maka pilihan prioritas yang sudah dibakukan, kadang-kadang memunculkan pertentangan antara kebutuhan hukum dan kasus-kasus tertentu. Sebab adakalanya dalam suatu kasus keadilan yang lebih tepat diprioritaskan ketimbang kemanfaatan dan kepastian hukum, tetapi dalam kasus lain justru terasa lebih tepat jika kemanfaatan lebih dipriotitaskan ketimbang keadilan dan kepastian hukum, dalam kasus lainnya justru kepastian hukum yang lebih tepat diprioritaskan ketimbang keadilan dan kemanfaatan.

Konsep termutakhir ini yang oleh dunia praktik hukum dianggap paling relevan untuk menjawab masalah-masalah hukum dewasa ini. Meskipun kita menganut teori ajaran prioritas yang kasuistik, tetapi harus

5 Sudarsono, Kamus Hukum Edisi Baru, Penerbit Rineka Cipta, Jakarta: Cetakan kelima, 2007, hlm. 37. diupayakan untuk memprioritaskan salah satunya, misalnya keadilannya tetapi tidak mengabaikan kemanfaatan dan kepastian hukumnya. Paradigma triangular concept dari Werner Menski harus digunakan, untuk mengharmoniskan ketiga unsur tersebut. ${ }^{6}$

Ketiga unsur itu sebisa mungkin ada dalam putusan secara proposioal, yaitu kepastian hukum (rechtssicherheit), kemanfaatan (zweckmassigheit), dan keadilan (gerechtigheit). Itu adalah idealnya. Dalam praktiknya jarang terdapat putusan yang mengadung tiga unsur itu secara proporsional. $^{7}$ Jadi Kepastian Hukum adalah tujuan paling akhir dari positivisme hukum. ${ }^{8}$

Menurut Fitzgerald, Teori perlindungan hukum Salmond bahwa hukum bertujuan mengintegrasikan dan mengkoordinasikan berbagai kepentingan dalam masyarakat karena dalam suatu lalu lintas kepentingan, perlindungan terhadap

\footnotetext{
${ }^{6}$ Ibid., hlm. 289.

${ }^{7}$ Sudikno Mertokusumo, Penemuan Hukum sebuah Pengantar, Yogyakarta: Penerbit Liberty, 2009, hlm. 92.

${ }^{8}$ Sulistyowati Irianto \& Shidarta, Loc.cit.
} 
kepentingan tertentu dapat dilakukan dengan cara membatasi berbagai kepentingan di lain pihak. $^{9}$ Kepentingan hukum adalah mengurusi hak dan kepentingan manusia, sehingga hukum memiliki otoritas tertinggi untuk menentukan kepentingan manusia yang perlu diatur dan dilindungi. ${ }^{10}$ Perlindungan hukum harus melihat tahapan yakni perlindungan hukum lahir dari suatu ketentuan hukum dan segala peraturan hukum yang diberikan oleh masyarakat yang pada dasarnya merupakan kesepakatan masyarakat tersebut untuk mengatur hubungan prilaku antara angota-anggota masyarakat dan antara perseorangan dengan pemerintah yang dianggap mewakili kepentingan masyarakat.

Menurut Satijipto Raharjo, Perlindungan hukum adalah memberikan pengayoman terhadap hak asasi manusia (HAM) yang dirugikan orang lain dan perlindungan itu diberikan kepada masyarakat agar dapat menikmati semua hak-hak yang diberikan oleh

\footnotetext{
${ }^{9}$ Satijipto Raharjo, llmu Hukum, Bandung: PT. Citra Aditya Bakti, 2000, hlm. 5.

${ }^{10}$ Ibid., hlm. 69.
}

hukum. $^{11}$ Menurut Phillipus M. Hadjon bahwa perlindungan hukum bagi rakyat sebagai tindakan pemerintah yang bersifat preventif dan resprensif. ${ }^{12}$ Perlindungan Hukum yang preventif bertujuan untuk mencegah terjadinya sengketa, yang mengarahkan tindakan pemerintah bersikap hati-hati dalam pengambilan keputusan berdasarkan diskresi dan perlindungan yang resprensif bertujuan untuk mencegah terjadinya sengketa, termasuk penanganannya di lembaga peradilan. $^{13}$

Menurut Lili Rasjidi dan LB Wysa Putra bahwa hukum dapat difungsikan untuk mewujudkan perlindungan yang sifatnya tidak sekedar adaptif dan fleksibel, melaikan juga predektif dan antipatif. $^{14}$ Perlindungan hukum merupakan gambaran dari bekerjanya fungsi hukum untuk

${ }^{11}$ Ibid., hlm. 54.

12 Phillipus M. Hadjon, Perlindungan Hukum bagi Rakyat Indonesia, Surabaya: PT. Bina Ilmu, 1987, hlm. 2.

13 Maria Alfons, Implentasi Perlindungan Indikasi Geografis Atas Produk-Produk Masyarakat Lokal Dalam Prespektif Hak Kekayaan Intelektual, Malang: Universitas Brawijaya, 2010, hlm. 18.

${ }^{14}$ Lili Rasjidi dan I.B Wysa Putra, Hukum Sebagai Suatu Sistem, Bandung: Remaja Rusdakarya, 1993, hlm. 118. 
mewujudkan tujuan-tujuan hukum yakni keadilan, kemanfaatan dan kepastian hukum. Perlindungan hukum adalah suatu perlindungan yang diberikan kepada subyek hukum sesuai dengan aturan hukum, baik itu yang bersifat preventif maupun dalam bentuk yang bersifat represif, baik yang secara tertulis maupun tidak tertulis dalam rangka menegakkan peraturan hukum. Pada hakekatnya setiap orang berhak mendapatkan perlindungan hukum, dan hampir seluruh hubungan hukum harus mendapat perlindungan dari hukum.

Keadilan merupakan suatu hasil pengambilan keputusan yang mengandung kebenaran, tidak memihak, dapat

dipertanggungjawab-kan dan memperlakukan setiap manusia pada kedudukan yang sama didepan hukum. Perwujudan keadilan dapat dilaksanakan dalam ruang lingkup kehidupan masyarakat, bernegara dan kehidupan masyarakat internasional, ditunjukkan melalui sikap dan perbuatan yang tidak berat sebelah dan memberikan sesuatu kepada orang lain yang menjadi haknya. ${ }^{15}$ Keadilan dapat juga diartikan sebagai suatu tindakan yang didasarkan pada norma-norma, baik norma agama maupun norma hukum.

Hans Kelsen dalam bukunya "General theory of law and state", berpandangan bahwa hukum sebagai tahanan sosial yang dapat dinyatakan adil apabila dapat mengatur perbuatan manusia dengan cara yang memuaskan sehingga dapat menemukan kebahagiaan di dalamnya. ${ }^{16}$

Nilai keadilan yang diangkat dalam tulisan ini bukanlah nilai keadilan individual, melainkan nilai keadilan sosial. Perwujudan nilai keadilan individual sangat ditentukan oleh masing-masing individu dalam melakukan interaksi di antara mereka. Berbeda dengan nilai keadilan individual, perwujudan nilai keadilan sosial sangat tergantung dari peranan negara melalui pengkondisian struktur sosial pada

\footnotetext{
${ }^{15}$ Sudikno Mertokusumo dalam H. Salim HS. Perkembangan Teori Dalam Ilmu Hukum, Jakarta: PT Rajagrafindo Persada, 2010, hlm. 82.

${ }^{16}$ Hans Kelsen, General Theory of law and state, diterjamahkan oleh Rasisul Muttaqin, Bandung: Nusa Media, 2011, hlm. 7.
} 
masyarakat tertentu. Jadi bukan tergantung kemauan individuindividu. Adanya keadilan, terutama sekali keadilan sosial merupakan suatu prasyarat untuk dapat berlangsungnya (sustainsibility) suatu komunitas tertentu karena komunitas tersebut dalam keadaan tertib (order), dinamis dan ketimpangan sosial dapat direduksi. Kondisi masyarakat demikian bukan berarti di dalamnya tanpa ada konflik. Konflik tetap ada, namun konflik tersebut bersifat fungsional dan dapat diselesaikan melalui mekanisme tertentu dengan menjunjung tinggi nilai keadilan (justice). ${ }^{17}$

\section{Eksekusi putusan atas} putusan Komisi Informasi hingga saat ini menjadi permasalahan bagi pencari keadilan sebab masih ada termohon sengketa informasi yang masih belum juga melaksanakan putusan Komisi Informasi yang telah berkekuatan hukum tetap. Disatu sisi pemohon informasi membutuhkan informasi dengan cepat, efektif dan biaya murah. Namun dalam

17 Prof. Dr. Suteki, SH., MHum., Desain Hukum di Ruang Sosial, Yogyakarta: Thafa Media, 2013, hlm. 248. kenyataannya hal tersebut tidak terjadi, karena pelaksanaan eksekusi putusan Komisi Informasi tidak menjadi kewenangan Komisi Informasi. Jika mengunakan teori Gustav Radbruch tersebut sebagai analisa maka keadilan bagi masyarakat atau pengguna informasi maupun pemohon informasi semakin jauh dari rasa keadilan serta perlindungan hukum. Hal demikian kemudian menjadikan Komisi Informasi tidak memiliki kekuatan eksekutorial terhadap putusannya sendiri

Sungguh ironis memang, hanya sekedar memperoleh informasi, kemudian pemohon atau pengguna informasi menempuh upaya yang begitu rumit, biaya cukup tinggi dan waktu begitu lama. Dengan prosedur eksekusi yang menyerupai prosedur eksekusi layaknya dalam perkara perdata di pengadilan. Kelembagaan pengadilan seharusnya tidak perlu sampai diberikan kewenangan untuk eksekusi, karena pertama penyelesaian sengketa informasi, pemeriksaan perkara tingkat pertama adalah Komisi Informasi, kedua 
perkara sengketa informasi merupakan perkara yang sangat sederhana, tidak seperti perkaraperkara lain dalam konteks perkara perdata di pengadilan negeri atau pengadilan tata usaha negara

Jika kita mau memberikan kewenangan kepada Komisi Informasi untuk melakukan eksekusi terhadap putusannya yang telah berkekuatan hukum tetap, sebenarnya masih sangat dimungkinkan sepanjang tata cara eksekusi, asas-asas eksekusi sebagaimana ketentuan peraturan perundang-undangan tidak dilanggar. Pemberian kewenangan tambahan kepada Komisi Informasi untuk melaksanakan eksekusi tersebut, sebenarnya untuk supaya hak konstitusional masyarakat, dalam hal ini pemohon informasi bisa dijalankan semaksimal mungkin dengan asas cepat, tepat waktu, biaya ringan dan cara sederhana

Apabila asas penyelesaian sengketa informasi yang dilakukan dengan cepat, tepat waktu, biaya ringan dan cara sederhana, sebagaimana pasal 2 Peraturan Komisi Informasi No.1 tahun 2013 dapat dijalankan sebagaimana mestinya, maka tujuan dari kepastian hokum, keadilan serta perlindungan hukum bagi pemohon atau pengguna informasi dalam penyelesaian sengketa informasi tercapai, sehingga hak konstitusional berupa hak memperoleh informasi, keadilan dan kemanfaat juga bisa dirasakan oleh pemohon informasi

\section{KESIMPULAN DAN SARAN}

Sengketa Informasi Publik adalah sengketa yang terjadi antara badan publik dan pengguna informasi publik yang berkaitan dengan hak memperoleh dan menggunakan informasi berdasarkan perundang-undangan.

Proses penyelesaian sengketa informasi publik dengan menggunakan mekanisme mediasi dan/atau ajudikasi nonlitigasi yang dilakukan oleh Komisi Informasi paling lambat dapat diselesaikan dalam waktu 100 (seratus) hari kerja Objek sengketa di PTUN yang secara tegas menunjuk Keputusan Tata Usaha Negara (KTUN) sebagai objek sengketa, UU KIP tidak mengaturnya secara tegas 
obyek sengketanya. Karena itu, untuk mengetahui objek sengketa informasi di Komisi Informasi, dapat dilihat dari ketentuan Pasal 35 ayat (1), Pasal 36, Pasal 37 ayat (2) UU No.14 tahun 2008 tentang Keterbukaan Informasi Publik

Eksekusi putusan atau pelaksanaan putusan Komisi Informasi dilakukan oleh Pengadilan yang berwenang. Pengadilan yang berwenang tersebut pengadilan dalam wilayah hukum termohon. Dengan kewenangan eksekusi putusan Komisi Informasi diberikan oleh pengadilan diwilayah hukum termohon, dalam hal ini jika termohon adalah badan publik Negara atau Pemerintah maka pengadilan yang dimaksud adalah Pengadilan Tata Usaha Negara, sedangkan jika termohon eksekusi adalah pihak diluar badan publik Negara atau Pemerintah maka pengadilan yang berwenang adalah Pengadilan Negeri yang berwenang

Komisi Informasi dalam rangka pelaksanaan putusan Komisi Informasi tidak memiliki kewenangan untuk melakukan eksekusi putusannya. Karena Komisi
Informasi tidak memiliki kewenangan melakukan eksekusi putusan Komisi Informasi, sehingga proses penyelesaian sengketa informasi menjadi lama, biaya tinggi, tidak sederhana

Dampak proses penyelesaian sengketa informasi hingga proses eksekusi yang melalui pengadilan yang berwenang tersebut menyebabkan hak konstitusional pemohon untuk mendapatkan informasi menjadi terhambat, sehingga cita-cita hukum untuk mencapai keadilan dan kemanfaatan menjadi terabaikan

Berdasarkan hasil penelitian dan pembahasan saran yang dapat diberikan oleh penulis adalah sebagai berikut:

1. Bagi Pemerintah

a. Dilakukan review dan perubahan terhadap Undang-undang No.14 tahun 2008 tentang Keterbukaan Informasi Publik, terutama berkaitan dengan kewenangan eksekusi terhadap 


$\begin{array}{lr}\text { putusan } & \text { Komisi } \\ \text { Informasi } & \\ \text { Memberikan } & \\ \text { kewenangan } & \text { eksekusi } \\ \text { kepada } & \text { Komisi } \\ \text { Informasi } & \text { untuk } \\ \text { melaksanakan } & \text { putusan } \\ \text { Komisi } & \text { Informasi } \\ \text { yang } & \text { telah } \\ \text { berkekuatan } & \text { hukum } \\ \text { tetap } & \end{array}$

2. Bagi Komisi Informasi

a. Dilakukan review dan perubahan terhadap Peraturan Komisi Informasi Nomor 1 Tahun 2013 tentang Prosedur

Penyelesaian

Sengketa Informasi

Publik

b. Dirumuskan

$$
\begin{aligned}
& \text { penyelesaian sengketa } \\
& \text { informasi dibuat } \\
& \text { sederhana dan waktu } \\
& \text { yang cukup singkat, } \\
& \text { sebab menyangkut } \\
& \text { rasa keadilan dan } \\
& \text { kepastian hukum bagi } \\
& \text { pemohon maupun } \\
& \text { pengguna informasi }
\end{aligned}
$$

3. Bagi Masyarakat

Partisipasi masyarakat diperlukan dalam melakukan review dan perumusan peraturan perundangundangan berkaitan penambahan kewenangan Komisi Informasi untuk melakukan eksekusi terhadap putusan Komisi Informasi yang telah berkekuatan hukum tetap, sehingga asas cepat, sederhana dan biaya ringan dalam penyelesaian sengketa informasi tercapai sehingga kepastian dan keadilan hukum terpenuhi

\section{DAFTAR PUSTAKA}

Ahmad Ali, 2010, Menguak Teori Hukum (Legal Theory) dan Teori Peradilan (Judicialprudence) Termasuk Interpretasi Undang-Undang (Legisprudence), Jakarta: Kencana Prenada Media Group, 2010.

Hans Kelsen, General Theory of law and state, diterjamahkan oleh Rasisul Muttaqin, Bandung: Nusa Media, 2011.

Lili Rasjidi dan I.B Wysa Putra, Hukum Sebagai Suatu Sistem, Bandung: Remaja Rusdakarya, 1993. 
Maria Alfons, Implentasi Perlindungan Indikasi Geografis Atas ProdukProduk Masyarakat Lokal Dalam Prespektif Hak Kekayaan Intelektual, Malang: Universitas Brawijaya, 2010.

Phillipus M. Hadjon, Perlindungan Hukum bagi Rakyat Indonesia, Surabaya: PT. Bina Ilmu, 1987.

Prof. Dr. Suteki, SH., MHum., Desain Hukum di Ruang Sosial, Yogyakarta: Thafa Media, 2013

Satijipto Raharjo, llmu Hukum, Bandung: PT. Citra Aditya Bakti, 2000.
Sudarsono, Kamus Hukum Edisi Baru, Penerbit Rineka Cipta, Jakarta: Cetakan kelima, 2007.

Sudikno Mertokusumo dalam $\mathrm{H}$. Salim HS. Perkembangan Teori Dalam Ilmu Hukum, Jakarta: PT Rajagrafindo Persada, 2010.

Sudikno Mertokusumo, Penemuan Hukum sebuah Pengantar, Yogyakarta: Penerbit Liberty, 2009.

Sulistyowati Irianto \& Shidarta, Metode Penelitian Hukum Konstelasi dan Reflekasi, Jakarta: Yayasan Pustaka Obor Indonesia, 2013. 